\title{
NATIONAL DEFENCE TRAINING OF PUBLIC ADMINISTRATION PERSONNEL IN POLAND
}

\author{
Col. Associate Professor Bogdan GRENDA \\ Lt. Col. Andrzej SOBOŃ, PhD \\ Faculty of National Security \\ War Studies University, Warsaw, Poland
}

\begin{abstract}
National defence training of public administration personnel can be broadly defined as a set of activities undertaken at all levels of public administration, aimed at preparing staff to perform official duties concerned with state defence. This paper opens with the presentation of essential areas of national defence training. The subsequent section provides an overview of implementations of national defence training at various levels of public administration and at Higher Universities. The final part of this analysis describes the assumptions of a new didactic framework of courses in defence for public administration and national authorities at the Faculty of National Security of War Studies University in Warsaw.
\end{abstract}

Keywords: training, defence, security, administration

\section{Introduction}

The sense of security is one of the rudimentary needs of individuals, social groups and entire nations. Nations deprived of security could not thrive or create organised, well-functioning structures. States, however, either through their deliberate activities (intentional events) or by the effect of forces of nature (independent and random events) are unable to indefinitely maintain top level security. Modern combat power is one of the prerequisites for both security during 
peacetime and success in a potential armed conflict; however, properly prepared educated citizens is the other - by no means less relevant. No state can disregard such potential, which is why one of the key objectives of a state is the organisation of preparation for defence activities, which can be of a military or non-military character. The military preparations are supervised by the Ministry of National Defence, while the non-military preparations lie within the scope of activities of other departments as well as of state and local administration authorities. National defence training is an element of non-military defence preparations.

National defence training ought to be treated as a particularly important area of the entire system of defence. It ensures efficient performance of defence tasks (by individuals to whom the tasks are assigned and that are included in the national defence training process) within other areas of preparation for the defence of the state. On the other hand, another vital element is the awareness of the necessity for active participation in preparation activities to practice responses in situations of particular threat to the state and during war.

It is for the abovementioned reasons that the aim of this paper was to identify the national defence training framework in Poland against the background of the state administration system and to indicate current and prospective solutions in the field.

\section{The essence of national defence training}

National defence training responds to the needs and potential in the aspect of preparation of non-military units, such as state and local administration, to fulfil tasks resulting from the need to support military units in response to current and prospective risks to state security. The training includes: preparation of managerial staff to perform tasks under the general defence obligation (as well as those participating in performing these tasks), developing the cooperation skills between organs and organisational units involved in defence activities with appropriate commands and organisational units of Polish armed forces or allied forces, preparation of the state defence system's elements to act during increased defence readiness and during wartime, shaping the defence awareness of people under training. 
The training is attended by heads of public administration departments and units, heads of subordinate and supervised organisational units, and employees of these units holding defence-related positions or those responsible for defence tasks, entrepreneurs performing defence tasks, as well as designated employees and individuals assigned to the Ready Reserve or the Armed Forces of the Republic of Poland.

The basic objective of national defence training is to pass the skills necessary for the performance of defence tasks and to improve qualifications in the performance of these tasks, as well as to teach the rules and procedures for managing defence tasks during increased state defence readiness and wartime. To paraphrase, the purpose of national defence training is to prepare heads of public administration, entrepreneurs and task teams (predominantly individuals in charge of defence activities in a given body, cell or organisational unit) to act in a situation of increased state defence readiness, which includes attaining a sufficient level of knowledge and skills required for the performance of defence tasks, specified in existing legal acts as well as in documents that are part of defence planning (such as in operational plans for the functioning of government administration departments and provinces).

\section{Scope of national defence training}

The scope of national defence training includes all individuals in charge of tasks under the general defence duty, as well as those involved in performing these tasks. According to relevant normative acts, national defence training involves:

1. managerial staff in public administration (including ministers, secretaries of state, under-secretaries of state and directors generals of ministries, persons performing the functions of Central Government Administration Bodies and their deputies, heads of central offices and their deputies, heads of other stateowned organisational units performing defence tasks and their deputies, as well as province governors and their deputies, marshals, poviat starosts, commune mayors, town mayors and presidents of cities and their deputies, directors of departments and their deputies, heads of offices and independent departments in offices under ministers, central offices and other state organisational units 
performing defence tasks, as well as directors of departments in provincial offices and their deputies);

2. heads of organisational units subordinate to and supervised by ministers, secretaries of state, under-secretaries of state, persons performing Central Government Administration Body functions, heads of central offices, heads of other state organisational units performing defence tasks, province governors, marshals, poviat starosts, commune mayors, town mayors and

3. presidents of cities (vide paragraph $\$ 3$ point 1 , a and b), and employees of these units holding defence-related positions or in charge of defence task performance matters;

4. entrepreneurs performing defensive tasks and their designated employees;

5. individuals, assigned to the Ready Reserve or the Armed Forces of the Republic of Poland.

It should be assumed that the phrasing used in the regulations: "in national defence training" expresses the unconditional obligation to participate. Therefore, according to the applicable law, the persons mentioned above are obliged to participate in the training process. The regulation also indicates those who may participate in training according to specific rules (optional participation), namely:

1. members of parliament and senators - by consent;

2. other individuals not included on the compulsory participation list - directed (by consent) to the body performing the function of national defence training coordinator by public authorities, trade unions, professional self-governing bodies, business and employer organisations, political parties, associations and foundations, as well as by chief editors of newspapers and magazines, radio and television programme broadcasters, opinion-forming centres and other institutions.

To recapitulate, heads of public administration (including ministers, their deputies and directors generals of ministries, heads of central offices and their deputies, province governors and their deputies, marshals, poviat starosts, commune mayors, town mayors and presidents of cities and their deputies) are obliged to participate, and MPs, senators and other persons may participate in national defence training conducted in the form of Higher National Defence Courses (HNDC). 


\section{National defence training at various levels of public administration}

The structure of each system ${ }^{1}$ (subsystem) is governed by at least two factors: the first is the target environment in which it is to function, and secondly, the functions and objectives to be achieved by a given system. Organisational structures are characterised by various criteria, including inter alia:

- the location of the system (subsystem) within the structure of the state defence system;

- the designation of the system (subsystem) to perform operational and support tasks;

- management range, according to the one-man management principle;

- determining the number of entities included in the developed system (subsystem) and establishing the links between them, defining the possible information flow;

- accounting for the immediate action performance potential of entities included in the system (subsystem);

- determining the degree of formalisation of the system (subsystem) and its effectiveness.

Developing the national defence training system based on these indicators, one must account for factors that will directly affect its functioning, such as: a rapidly changing environment that requires the system to exhibit great functional flexibility; the fact that the size of the organisational structures of individual subsystems will affect the manageability of the system; the culture of subsystem elements in terms of common standards and values; skills of managerial staff in lower organisational structures of the system. It should therefore appear that every organisational structure must contain hierarchically ordered and deliberately chosen elements, as well as take into account the relations and relationships of various types between its particular links. It is only by developing the structure of the organisation based on the principles described above that we can ensure the effective organisational structure of each system or subsystem.

1 "Structure" is understood as the system and relationships between its constituents. Source: own translation based on (Stownik wyrazów obcych PWN 1980, p. 706). 
The organisational structure has regulatory functions within the organisation. It enables shaping the internal order by determining the place of each of the elements within the organisational system; what is more, it leads to developing desired ways of operation. Therefore, the structure predominantly serves management needs. Established in a conscious manner and defined in the organisational documentation, the relationships merge and organise the system elements, thus enabling efficient management of the entire complex organisational structure of the system.

"Public administration" may be understood as all of the activities performed by various actors, bodies and institutions for the benefit of the public interest. Although admittedly simplified, the definition may still prove difficult to understand. The term may be better understood through presentation of the three groups of actors this body is composed of.

The first group is the state administration, not subordinate to the government. This group includes, inter alia, the President of the Republic of Poland, the Supreme Audit Office, the National Broadcasting Council, the Polish Ombudsman, the National Council of the Judiciary, and the National Bank of Poland.

Government administration is the organisational structure of public administration, composed of central and local authorities. At the central level, the government administration consists of the Council of Ministers, Prime Minister, vice presidents of the Council of Ministers, ministers, and chairmen of committees, which are referred to as primary organs of government administration. The most important of these is the Council of Ministers, because according to the Constitution of the Republic of Poland, it is this body that is appointed to run the government administration. In addition, the central level administration includes central government administration bodies that are subject to the abovementioned bodies, i.e. Prime Minister or individual ministers.

Currently, the responsibility for the preparation and execution of the national defence training at organisational units at the central level lies with the Office of the Council of Ministers, which, in accordance with the law on the general defence duty of the Republic of Poland, manages three foundations of the defence education system, i.e. civil defence, militarised units and general civil self-defence. Under this act, the Office of the Council of Ministers defines: 
- tasks, responsibilities, the scope of power for state administration bodies to cooperate in response to natural disasters and general rules for creating civil defence formation;

- tasks related to theoretical and practical training, control and rules for equipping militarised units;

- principles and dimensions of basic training and time of practical exercises within the framework of general civil self-defence.

The Prime Minister is in charge of organising national defence training, which takes one of the following forms:

- international and national exercises that are carried out at least once every five years,

- regional exercises covering the area of two or more provinces, which are carried out at least once every two years,

- Higher National Defence Courses conducted at the War Studies University.

- In terms of government administration departments, the national defence training organiser is the respective minister, and the training itself is conducted in the form of:

- theoretical and practical classes carried out in the annual cycle,

- department exercises carried out at least once every two years.

The last group is the local government administration on three levels - commune, poviat and province. The bodies of each local government unit carry out public tasks in the area of their local jurisdiction - their area of operation. The territorial self-government performs its tasks in order to meet the needs of people living in the area of operation of a given organisational unit.

The province (voivodeship, in Polish: województwo) is the basic organisational unit of the country division and, therefore, fulfils a key role in the functioning of the state defence system. Under the management of province governors, the defence tasks pertaining to the non-military system of civil defence education are integrated and performed. The province governor's defence-related tasks consist in:

- maintaining the efficiency of national and local administration;

- maintaining business continuity of basic plants operating in the area of the province;

- protection of the population and material goods;

- maintaining order and security, with efforts intensified during wartime; 
- distribution of forces and resources for the preparation of defence zones, nodes or facilities;

- providing necessary materials to the armed forces.

The province and poviat-range courses are organised with the intention of:

- familiarising the personnel with national defence tasks, as well as the rules and procedures for their execution, not to mention the normative and legal provisions in the field of defence within the framework of general collective defence;

- improving and/or checking the ability to perform or solve defence tasks in modelled situations and to improve the teamwork of individual organisational units as part of specialised exercises, decision-making games and training;

- perfecting solutions and performing tasks in the process of increasing state defence readiness and the functioning of the wartime control system, as well as correlating the activities of the most important organisational and functional structures of individual ministries and provinces within integrated departmental and provincial exercises.

Another element of the defence system, directly subordinate to the province in terms of defence is the commune, whose tasks involve:

- preparing the population for the execution of the general defence duty and cooperation with military authorities;

- activities under the general defence duty in cooperation with military authorities;

- personal, material and special benefits for state defence;

- civil protection tasks resulting from the function of the president (commune mayor) as the head of civil defence of the commune.

The functionality of the defence education system determines the quality of the preparation of the population, inter alia in the field of self-defence in the event of peace and war threats. At the level of the province, poviat and commune, national defence education should be based on the cooperation of the state local administration with the local government administration in the scope of their function and role in the national civil protection system, coordination of rescue operations with the army, the forces of law and order, and technical rescue services in the fight against disasters and their consequences based on a pre-established programme. 


\section{National defence training at universities}

Defence projects carried out at universities are regulated by respective laws ${ }^{2}$. Among departmental legal regulations concerning higher education, the notable act is the Act of 27 July 2005 - Law on Higher Education and Regulation No. 63/2011 of the Minister of Science and Higher Education of August 18, 2011 on the principles of planning, organisation and execution of tasks under the general defence duty.

The provisions of the Act - Law on Higher Education - do not refer directly to defence problems. However, their importance lies in the fact that they draw the general, organisational framework, determine the competencies and regulate the organisational matters of the university. The articles of particular importance are: 13, 33, 40, 66, 227 and 229. The most important regulation, however, is established in Article 70 of the Constitution and specified in Art. 4 of the Act on the autonomy of universities.

Regulation No. 63/2011 is the major executive document concerning the science and higher education, which comprehensively regulates the issues of planning, organising and execution of tasks under the general defence duty in the Ministry of Science and Higher Education and organisational units subordinate to the minister and units under its supervision. The planning and organisational activities are referred to in the ordinance focus on the implementation of defence tasks assigned to universities by the Minister. The document details several dozen projects planned for implementation with a view to attaining higher states of defence readiness of the state, i.e. in crisis and in wartime, which require preparation in peacetime. In addition, the ordinance draws attention to the organisation and implementation of national defence training with employees.

2 Major acts include: Act of 21 November, 1967 on General Defence Duty of the Republic of Poland; Regulation of the Council of Ministers of 21 September, 2004 on Readiness to Defend the Country; Regulation of the Council of Ministers of 13 January 2004 on General Principles for the Execution of Tasks under General Defence Duty; Act of 29 August 2002 on Martial Law and Competence of the Supreme Commander of Armed Forces and the Principles of His Subordination to the Constitutional Authorities of the Republic of Poland. 
Regarding national defence training, the minister sets out the main directions and objectives for a given year with its annual regulation. However, since the national defence training described in the regulation is devoted solely to the personnel defensive education for students is not provided. In other words, from the formal viewpoint, the national defence training organised by universities does account for student needs.

In fact, no relevant "military" courses had been organised since the elimination of military activities in 1991 from the military studies programme of universities subject to the Ministry of National Education. However, in 1995, the Ministry of National Defence initiated National Security Studies at the University of Warsaw. The curriculum included such spheres as: international security; Poland's defence system and defence policy; integration of Poland with NATO structures, general defence and economic defence tasks.

At present, there are a dozen or so universities educating students in the security issues, which are the source of the inflow of trained personnel to manage broadly defined defence and defence tasks in the Republic of Poland.

Theseuniversitiesinclude:LechKaczyńskiNationalSchoolofPublic Administration, Pedagogical Universities of Cracow and Bydgoszcz, Siedlce University of Natural Sciences and Humanities, Pułtusk Academy of Humanities. Furthermore, national defence is incorporated in the curricula of medical universities and maritime universities. By comparison, the War Studies University (transformed in 2016 from the National Defence University in Warsaw) is among the key providers of trained defence personnel for both military and civil service. The relevant training is implemented within the curricula of: Higher National Defence Courses, postgraduate Operational and Strategic Study, post-graduate State Defence Studies, extramural post-graduate Studies in Defence Education, extramural Bachelor and Master's studies in Management and Marketing, the curricula of both of which incorporate economic/defence and economic/military problems. At present, the War Studies University, with its headquarters in Rembertów, trains the senior management staff of the ministries and provinces.

Since 1994, Higher National Defence Courses have been organised by the National Security Department of War Studies University (former National Defence University), under the supervision of the Prime Minister - the organiser 
of the HNDC. Higher National Defence Courses must conform to the Regulation of the Council of Ministers of January 13, 2004 on national defence training3. The amendment to the document in question of June 6, 2007, concerned mainly $\$ 5$, which now reads that the Prime Minster is an organiser of training courses in the form of international and national courses carried out at least once every five years. Simultaneously, the document states that it is the Minister of National Defence who is the organiser of Higher National Defence Courses and regional national defence training (over the area of two or more provinces), and that the latter should be carried out at least once every two years ${ }^{4}$. These changes were introduced for practical reasons: the present powers of the Minister of National Defence include all the aspects of national defence training; therefore enabling the introduction of any necessary changes in a straightforward and immediate fashion.

To ensure the appropriate level of course organisation, the courses are based on the common document - the Higher National Defence Course Programme, which contains the action plan and a strategy for achieving specific course objectives (the 2018 Syllabus of Higher National Defence Courses, 2017). The programme is created for a five-year perspective; however, it is revised not every five years, but virtually on an annual basis. Such frequent revisions of the curriculum, despite their long-term nature, are dictated by the need to update and adapt the programme to changing requirements and to anticipated challenges, opportunities and threats

3 Dziennik Ustaw of 2004 [Journal of Laws] No.16, item 150, as amended. Training in the subject area of courses in question were first regulated in 1994 by virtue of the resolution of Council of Ministers No. 72 of 4 October, 1994 on Defence Training of Managerial Personnel of Public Administration Monitor Polski UW of 1994, No. 56, item 482. Another secondary legislation of the said resolution was the Regulation No. 113/MON of the Ministry of National Defence of 7 December, 1994 on Introduction of Higher National Defence Courses to the National Defence University, within which, paragraph $₫ 2$ obliged the National Defence University Rector to elaborate a detailed training plan. Another secondary legislation was the incorporation of Higher National Defence Courses in the curriculum, by the decision of the Secretary of State regarding the organisation and support of the functioning of Higher National Defence Courses for managerial personnel of public administration at the National Defence University (Dziennik Ustaw of 2004 [Journal of Laws] No.16, item 150, as amended).

4 Prior to the amendment, it was the Prime Minster who was the designated organiser of training courses on international, national and regional levels (covering the area of two or more provinces) carried out at least once every two years and Higher National Defence Courses conducted at the National Defence University. 
to state security. At the end of each training cycle, which lasts from January to the end of November, a conference is organised to exchange experiences and views on the substantial, methodological and organisational assumptions of the training process as part of the Higher National Defence Courses, as well as to evaluate its implementation (Minutes of the Higher National Defence Courses Methodological Conference at the National Defence University, 2017) and propose changes to the programme and organisation for the subsequent year.

The objective of Higher National Defence Courses is to develop awareness about security and defence. Considering the number of actors having an influence on state defence at all its levels (commune, poviat, province or central level), it is therefore deemed necessary to ensure uniform training at all levels. Bearing in mind that apart from the sheer number of involved actors, many of these entities are totally independent of each other, it becomes apparent that cooperation in the face of threat would be impossible without a common foundation of knowledge, a uniform area of principles that would allow time-wasting in the crucial moment on determining competences, rules, organisation and subordination to be prevented and devoted instead to acting. On the other hand, only joint training and joint exercises can provide such a foundation (Wiśniewski 2010, p. 79). Defensive education plays an indispensible role in integrating societies and local communities faced with either war threats or various threats encountered in peacetime (Bieńkowski, Kucharski, Stępień, 1998, p. 85); it, moreover, plays the same integration role among the administrative staff.

According to the Act, the purpose of organising Higher National Defence Courses at the War Studies University is to develop the defence awareness of students, provide them with the necessary knowledge and skills, as well as to improve their qualifications. An additional goal is to improve their knowledge of procedures and rules governing defence activities both during war or when the defence readiness of the state is increased (Makowski, Piątek 2012, p. 61). These objectives are achieved through the performance of specific tasks, both theoretical and practical. The following tasks are carried out within the didactic process:

a) learning the facts, phenomena and concepts in the field of state security and defence, exploring the issues of the national security strategy of the Republic of Poland and learning the laws and dynamics governing the defence of both the state and its citizens; 
b) improving and facilitating operation within tasks and procedures concerning state defence readiness and economic-defensive preparation, responding to the needs of the Polish Armed Forces, and implementation of Civil Defence tasks;

c) consolidation of knowledge, the key point of any learning process;

d) developing skills and habits desired in the field of safety and defence of the public administration management personnel, as well as developing the ability to use the acquired knowledge and qualifications in practice;

e) developing the cooperation skills and cooperation between organs and organisational units of central and local government administration with the headquarters and organisational units of the armed forces in planning and managing crisis situations engendered by threats in times of peace or war;

f) developing instinctive habits of operation in civil protection in the event of extraordinary threat;

g) preparing the public administration managerial staff to perform defensive tasks in times of peace, of increased defence readiness and during wartime;

h) improving the knowledge and skills of individuals in charge of defensive tasks following from operational plans and learning the procedures of management and task execution systems in all states of defence readiness (at the central, province and poviat level) (The 2018 Syllabus of Higher National Defence Courses 2017; Ratajczak 2011, p. 52).

Classes within the curriculum of HNDC are predominantly conducted in the form of lectures and seminars. These account for over half of the total didactic time. Lectures and seminars explore a range of issues of state security criteria, the functioning of institutions responsible for security, vision and security concepts, as well as analyse strategic documents ${ }^{5}$. The HNDC didactic programme includes: the fundaments of organisation, the purpose of training, participants in defence courses, groups in which the courses will be organised, training topics and organisation issues.

5 The classes are conducted with adherence to an 8-hour day of didactic classes (08:0015:30) and 4 afternoon slots (18:00 - 22:00). On average $13-15$ groups are taught annually over an average of $16-18$ meetings. Depending on the constitution of the groups, the session lasts from 5 to 10 days. Based on: http://aon.edu.pl/pl/wko/287-o-wyzszychkursach-obronnych. 
Higher National Defence Courses are focused on defence in its broadest sense and include the following modules: "External Factors of the National Security of the Republic of Poland;" "Preparation of state defence Management System;" "Strategic Aspects of Euro-Atlantic Security;" "The Place and Role of Public Administration in the National Host Nation Support (HNS) Model;" "Rules of Civil-Military Cooperation;" "Programming and Rules of Financing NonMilitary Defence Preparations;" "Strategic Defence Review;" "Geostrategic Factors Conditioning Poland's Security;" "Security Threats for the Republic of Poland;" "Non-Governmental Organisations in state defence System;" "National Security Strategy of the Republic of Poland and the Defence Strategy of the Republic of Poland;" "Crisis Management System in NATO and the EU $U^{6}$." The listed topics constitute only a part of the entire syllabus, which consists of 16 problems defined by $\$ 7$ of the Regulation of the Council of Ministers of 13 January 2004 on National defence training. Each problem area is approached from several perspectives defined in the 2011-2016 Syllabus of Higher National Defence Courses.

Each course leads to the final phase - games and exercises, organised in three stages: first - giving instructions to the decision game; second - the decision game in which real reactions to political/military crises are practiced; and finally - the feedback stage when the management team solutions and defensive decisions taken in the game are verified (The 2018 Syllabus of Higher National Defence Courses, 2017).

It becomes apparent from the preceding paragraphs that the programme of Higher National Defence Courses is directly devoted to the state defence system, according to which the tasks are divided between the military, non-military and defence management systems. This classification enables the didactic material of the course to be divided accordingly into modules; in the military module there are: geostrategy, threats, armed conflicts, Polish Armed Forces their place, role, functions, tasks, comparison with the forces of other countries, and defence problems; the non-military module consists of: economy, defence education, threat monitoring, rules of conduct, civil protection, state structures, classified information, interactions between ministries, units and services, as well as civil defence, and legal and organisational issues; whereas the state defence

6 Own translation based on http://www.aon.edu.pl/pl/wko/427-opisy-tematow-wko. 
module concerns aspects of: state defence management, i.e. the security policy, the defence strategy of the Republic of Poland, as well as the concepts and tasks of administrative bodies in the area of state security and defence (Kardas 2000, pp. 32-35).

Higher National Defence Courses provide qualification and knowledge to the personnel of public administration; consequently, they meet the major requirement for the state defence system: to integrate defence needs, economic capabilities, organisational efficiency and to ensure continuity of individual state structures (Makowski, Piątek 2012, p. 63).

\section{A new concept of education of public administration and state authorities}

In 2018, the National Security Department of War Studies University developed a proposal for a new "Education Concept for the State Authorities Representatives and Public Administration Personnel." According to the model assumptions, the education is directed to the ministry management, heads of departments and of organisational units of the ministry, including the organisational units of the Ministry of National Defence and personnel of the lower administrative level. In addition, the course embraces the group of representatives of the political power in the strategic security management.

The concept of education is based on three directions (paths) profiled and dedicated to public administration personnel, including the Ministry of National Defence administration and state authorities (members of parliament and senators). The length and content of the course is adjusted to the specificity of the tasks carried out by particular professional groups working for the Ministry, namely: public administration personnel at the central, province and county levels, and the departmental administration of the Ministry. The offer also reaches out to the managerial staff of the political and strategic levels of the state, including representatives of the Sejm and the Senate of the Republic of Poland.

The developed concept includes three personnel training paths:

1. Education of public administration personnel, 
2. Education of the Ministry of National Defence administration,

3. The path of education of the state authorities.

The didactic path for public administration includes content in the field of state security management in peace, crisis and war, emergency states, the functioning of the state defence system and preparation and implementation of defence tasks in the country. In addition, the scope of the curriculum embraces the assumptions and formal and legal conditions of security, state defence and defence tasks performed by public administration personnel, enterprises and decision-making centres of state central, province and county state authorities.

As part of the training, the didactic path for public administration personnel also includes materials from specialist courses concerned with integrated state security, crisis management, defence preparations and the state defence system, theoretical and practical assumptions of internal security, decision-making and correlation of specialised power, support, protection and defence subsystems.

The key element in this path is to raise the level of knowledge and practice of public administration personnel in the performance of administrative and decision-making activities, cooperation and assistance of public administration with private, state and departmental actors, including national and allied armed forces.

The didactic path for the Ministry of National Defence administration concerns the employees of public administration and heads of the Ministry of National Defence and organisational units of other ministries and institutions operating on behalf of the defence and security of the state, local government units and entrepreneurs in terms of preparation to conduct and develop administrative duties, notwithstanding decision-making, in the field of national defence. The training involves planning, organising and implementing broadly understood defence projects in accordance with the latest legal, doctrinal and organisational concepts in the public administration.

Within the didactic path for state authorities, the curriculum includes information related to contemporary threats and opportunities, both on the international, regional and national level, in such areas as: politics/military, geopolitics, information, socio-economics, and culture. In the scope of education, the participants will learn about Polish defence policy in relation to the protection 
of the democratic sovereignty of the state and the improvement of the defence capabilities of the armed forces, as well as cooperation and joint activities with allies. Current challenges and threats support and create the fundaments for the decision-making, planning and organisation of remedial and pre-emptive actions for event management during peace time, as well as in the face of specific security threats, of both military and non-military character.

In addition, this didactic path provides the necessary knowledge in terms of skills and decision-making competencies towards initiation and implementation of optimal solutions for counteracting potential threats, which are furthermore linked to elements of risk management.

Education along all paths will be carried out in the form of:

- two-semester post-graduate studies,

- 2-week short-term courses,

- 1-2 day short-term specialist training courses (Saturday-Sunday).

\section{Summary}

Nowadays, the scope of state defence extends beyond the problem of the armed forces alone. The approach to state defence includes not only military forces engaged in combat with enemy units, but also all areas of the state and social life that, without directly partaking in fighting, should contribute to effective state defence. Engagement of additional spheres of life in the defence of the country follows from the awareness of the specific nature of modern warfare, which affects the entire nation and the territory of the state. Therefore, it is of utmost importance to prepare society for defence and to shape the patriotic and defensive awareness of citizens.

National defence training is conducted in order to develop skills necessary to perform defence tasks and improve qualifications in the performance of these tasks, as well as to learn the rules and procedures for managing defence tasks while increasing state defence readiness and in wartime. The training is carried out in the form of theoretical and practical classes and exercises, including training and different-range simulation games: from the field, province, regional, national 
to international level, during which the complex problems of preparation and execution of activities are solved in the context of a real or close-to-real situation in conditions of threat to state security or during wartime. To a certain extent, the exercises within the course are carried out with the use of elements of the state infrastructure planned for use in the event of external security threat including wartime, as well as involve the participation of full-time or ad hoc functional teams designated to perform defence tasks.

National defence training is also conducted in the form of Higher National Defence Courses and related forms of education at state universities, including military academies.

Higher National Defence Courses are organised at the War Studies University and constitute a vital aspect of state defence. They play a unique role in instilling awareness, improving qualifications and skills of the national and local administration personnel in charge of tasks under the general defence obligation. The courses are developed on the uniform knowledge and information base, necessary for the smooth functioning of the national and local administration in the event of threat, as well as its seamless cooperation with the armed forces. For years, the primary advantage of the courses has been their skilful adaptation to the current situation on the international arena.

\section{References}

Bieńkowski, J., Kucharski, M., Stępień, R., 1998. Koncepcje i kierunki przemian edukacji dla bezpieczeństwa, National Defence University, Warsaw.

http://aon.edu.pl/pl/wko/287-o-wyzszych-kursach-obronnych [Accessed 22 Sep 2018].

http://www.aon.edu.pl/pl/wko/427-opisy-tematow-wko [Accessed 24 Sep 2018].

Kardas J.S., 2000., Wyższe Kursy Obronne. Analiza - ocena - perspektywa, National Defence University, Warsaw.

Koncepcja ksztatcenia przedstawicieli władz państwowych $i$ kadr administracji publicznej, 2018. War Studies University, Warsaw.

Makowski P., Piątek Z., 2012. Wyższe Kursy Obronne na przestrzeni piętnastu lat. In XV lat Wyższych Kursów Obronnych - Edukacja obronna kierowniczej kadry administracji publicznej, Z. Piątek, B. Wiśniewski (eds), National Defence University, Warsaw. 
Minutes of the Higher National Defence Courses Methodological Conference at the National Defence University on 30 November, 2017. Warsaw.

Ratajczak R., 2011. Organizacja i przebieg szkolenia w ramach Wyższych Kursów Obronnych. In XV lat Wyższych Kursów Obronnych - Edukacja obronna kierowniczej kadry administracji publicznej, Z. Piątek, B. Wiśniewski (eds), National Defence University, Warsaw.

Stownik wyrazów obcych PWN, 1980. Warsaw.

Wiśniewski B., 2010. Szkolenie obronne pracowników administracji publicznej (diagnoza i postulaty). In Z. Piątek, B. Wiśniewski (eds), XV lat Wyższych Kursów Obronnych - Edukacja obronna kierowniczej kadry administracji publicznej. National Defence University, Warsaw.

The resolution of Council of Ministers on Defence Training, 2004. Dziennik Ustaw of 2004 [Journal of Laws] No.16, item 150.

The 2018 Syllabus of Higher National Defence Courses, 2017. The Strategy and Defence Planning Department of the Ministry of National Defence MON, Warsaw. 